\title{
Chasing the Other "Populist Zeitgeist"? Mainstream Parties and the Rise of Right-Wing Populism
}

\author{
Michael Bayerlein (iD
}

Received: 8 June 2020 / Revised: 23 December 2020 / Accepted: 6 January 2021 / Published online: 8 February 2021

(C) The Author(s) 2021

\begin{abstract}
This article answers the question of why certain European mainstream parties have changed their policy positions on the GAL-TAN (Green/Alternative/ Libertarian vs. Traditional/Authoritarian/Nationalist) dimension in recent years. I argue that these changes can be explained through the electoral success of new rightwing populist parties and the ideological proximity of conservative mainstream parties towards these parties. These arguments were tested with econometric models of mainstream parties' policy positions in 11 Western European democracies between 2002 and 2019. The results indicate that mainstream parties chase the other "populist zeitgeist" by changing their policy positions on the GAL-TAN dimension in response to the electoral success of right-wing populist parties. Mainstream parties respond to this threat by closing the distance to these parties on the GAL-TAN dimension. However, this responsiveness is largely constrained to conservative mainstream parties. The findings have important implications for understanding mainstream party responsiveness towards rivalling right-wing populist parties.
\end{abstract}

Keywords Populism · Electoral competition - Spatial analysis · Political parties · GAL-TAN Dimension

All figures were created with Stata SE 15 (StataCorp. 2017. Stata Statistical Software: Release 15. College Station, TX: StataCorp LLC).

Supplementary Information The online version of this article (https://doi.org/10.1007/s11615-02100299-x) contains supplementary material, which is available to authorized users.

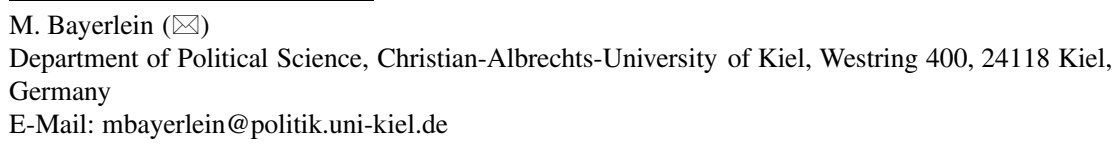

Research Center International Finance and Macroeconomics, Kiel Institute for the World Economy, Kiellinie 66, 24105 Kiel, Germany 


\section{Verfolgung des anderen populistischen ,Zeitgeists“? Europäische Mainstreamparteien und der Aufstieg des Rechtspopulismus}

Zusammenfassung Dieser Artikel beantwortet die Frage, warum bestimmte europäische Mainstreamparteien ihre politischen Positionen zu Themen wie Migration und europäische Integration geändert haben. Ich argumentiere, dass diese Veränderungen durch den Wahlerfolg rechtspopulistischer Parteien und die ideologische Nähe konservativer Mainstreamparteien zu diesen Parteien auf der GAL-TAN(Green/ Alternative/Libertarian vs. Traditional/Authoritarian/Nationalist)-Dimension erklärt werden können. Diese Argumente werden getestet, indem ökonometrische Modelle der politischen Positionen von Mainstreamparteien in 11 westeuropäischen Demokratien zwischen 2006 und 2017 geschätzt werden. Die Ergebnisse zeigen, dass Mainstreamparteien dem populistischen ,Zeitgeist“ nachjagen, indem sie ihre Positionen auf GAL-TAN-Dimension als Reaktion auf den Wahlerfolg rechtspopulistischer Parteien ändern. Mainstreamparteien reagieren auf die Bedrohung durch diese Wahlerfolge, indem sie die Distanz zu diesen Parteien auf der GAL-TANDimension verringern, um die an rechtspopulistische Parteien verlorenen WählerInnen zurückzugewinnen. Diese Responsivität ist jedoch weitgehend auf konservative Mainstreamparteien beschränkt. Die Ergebnisse haben wichtige Implikationen für das Verständnis der Responsivität von Mainstreamparteien gegenüber rivalisierenden rechtspopulistischen Parteien auf der GAL-TAN-Dimension.

Schlüsselwörter Populismus · Wahlkampf · Räumliche Modelle · Politische Parteien · GAL-TAN Dimension

\section{Introduction}

In recent years, several European mainstream parties ${ }^{1}$ have turned towards more nationalist policy positions, with the Österreichische Volkspartei (ÖVP) campaigning for tightening the national asylum law in the 2017 Austrian national election, the British Conservative Party leading the United Kingdom out of the European Union (EU), and the Danish Venstre (V) closing the borders to control the inflow of migrants, to name only a few examples. However, during the same time period, other mainstream parties have not changed their positions regarding issues such as European integration or migration, e.g., the Dutch Partij van de Arbeid (PvdA), the Italian Partito Democratico (PD), and the German Sozialdemokratische Partei Deutschlands (SPD).

What makes this observed variance in position changes particularly interesting is that issues such as migration and European integration are not related to the classic

\footnotetext{
1 Mainstream parties are parties that belong to either the socialist, conservative, or liberal party family; are continuously competing in national elections; and are frequently the majority party in government coalitions or at least win a considerable number of votes. The coding is based on the ParlGov database (Döring and Manow 2019). The criteria are applied to the entire period covered by ParlGov and not only to the period under research. The coding is time invariant over the course of the analysis.
} 
socioeconomic left-right dimension. Rather, these issues are embedded in a newly politicised cultural dimension in terms of Green/Alternative/Libertarian (GAL) vs. Traditional/Authoritarian/Nationalist (TAN) issues (see Hooghe et al. 2002). The observed movement of mainstream parties on this GAL-TAN dimension is puzzling because basic premises of Lipset and Rokkan's (1967) cleavage theory suggest that mainstream parties are rather inflexible when it comes to new issue dimensions (see also Hooghe and Marks 2018). Because of this inflexibility, mainstream parties supposedly depoliticised the GAL-TAN dimension to retain the electoral competition to the socioeconomic dimension (Kriesi and Hutter 2017; Kriesi et al. 2006; Mair 2007).

In light of the observed changes in mainstream party policy positions on the GAL-TAN dimension, this article addresses the research question of why several European mainstream parties have changed their policy positions on the GAL-TAN dimension in recent years. To answer this question, I combine the cleavage theory with considerations on party responsiveness derived from Downsian models of spatial electoral competition (see Downs 1957). The argument I make is twofold. First, I argue that the between-country variation in the position changes of mainstream parties can in part be explained by differences in the success of right-wing populist parties (RWPPs). Second, I argue that the within-country variation is dependent on the ideological proximity of conservative mainstream parties to RWPPs on the GALTAN dimension.

In defining RWPPs, I follow the populism definition given by Mudde (2004, p. 543), according to which it is a thin ideology that considers society to be "separated into two homogeneous and antagonistic groups, 'the pure people' versus 'the corrupt elite."' The defining characteristic of right-wing populist parties is that they take strong conservative and nationalist positions and emphasise traditional cultural and moral values, national self-interest and identity, and authority (Rydgren 2005). This makes RWPPs a new party type because they combine the issues of old radical right-wing parties with new right-wing GAL-TAN positions and a populist rhetoric that centres around the alleged failure of "the elites" to address the policy preference of "the people" on the GAL-TAN dimension (Zaslove 2008). In many countries this is a novel policy position, which has been proven beneficial for RWPPs and malicious for mainstream parties.

Altlhough I focus on RWPPs and their impact on the policy positions of mainstream parties on the GAL-TAN dimension, important insights can already be drawn from previous contributions that have addressed how parties react to radical rightwing parties. A contagious effect of rivalling radical right-wing parties has already been shown by van Spanje (2010) and Abou-Chadi and Krause (2020), who found that mainstream parties react to these parties on migration and European integration issues. Focusing on the influence of Eurosceptic parties, Meijers (2017) as well as Wagner and Meyer (2017) confirm this development. Shifting the focus to Eastern and Central European countries, Heinisch et al. (2021), however, do not confirm this trend. Thus, the rich literature on radical right-wing parties points to a responsiveness of Western European mainstream parties towards radical right-wing parties on single issues. 
However, studies dealing with mainstream party responsiveness towards rivalling right-wing populist parties on the GAL-TAN dimension in general are still scarce. The existing studies focus on whether mainstream parties follow the populist antielite rhetoric (e.g., Rooduijn et al. 2014), only address single cases (e.g., Arzheimer and Berning 2019) and single issues such as migration (e.g., Pardos-Prado 2015) or other policy dimensions (Krause and Giebler 2020), or do not account for specific party characteristics (e.g., Guiso et al. 2017; Schumacher and van Kersbergen 2016). One of the few comprehensive analyses comes from Mudde (2013), who found no systematic impact of RWPPs on mainstream party GAL-TAN policy positions - a finding he ascribes to the modest success of RWPPs in the late 20th century.

Given the recent electoral success and the observed policy position changes of mainstream parties, I build on the vast field of research contributions on radical rightwing parties and address a still remaining gap in the literature. This is done in three ways, by (1) analysing right-wing populist parties, (2) using the electoral success in terms of vote share, and (3) focusing on the position changes of mainstream parties on the GAL-TAN dimension. In doing so, I contribute to the debate on the impact of RWPPs by drawing on arguments from spatial models of electoral competition and providing evidence that first-and-foremost conservative mainstream parties are responsive to the electoral success of RWPPs on the GAL-TAN dimension.

The paper is organised as follows: I first elaborate on the GAL-TAN dimension and describe why mainstream parties sought to depoliticise it. Subsequently, I discuss the recent electoral success of RWPPs and argue why and how mainstream parties have changed their policy positions on the GAL-TAN dimension. In the empirical section, I estimate econometric models concerned with the responsiveness of 25 mainstream parties on the GAL-TAN dimension towards the electoral success of RWPPs in 11 European countries between 2002 and 2019.

\section{The GAL-TAN Dimension in the European Policy Space}

The European policy space can be conceptualised as two-dimensional, with a socioeconomic and a cultural dimension facing each other orthogonally whilst simultaneously being interrelated to some degree (see, e.g., Hooghe et al. 2002; König et al. 2017). Whereas the socioeconomic left-right dimension has been rather stable in structuring electoral competition and the formation of parties over the 20th century (Mattila and Raunio 2006), the cultural dimension has been highly flexible over time, with issues such as European integration and migration becoming incorporated into this dimension and making the conflict over transnational issues part of the cultural dimension often termed the GAL-TAN dimension (Hooghe and Marks 2018; de Vries 2018).

In this regard, it is important to note that issues like European integration and migration are not exclusively linked to the GAL-TAN dimension. Rather, these issues can also be linked to the socioeconomic dimension (see Armingeon et al. 2015; Hooghe et al. 2002; Hobolt 2016). This complex relationship of the two dimensions is underscored by the fact that (socio)economic crises can be framed as cultural conflicts and vice versa (see Rodrik 2018). This is, however, less of 


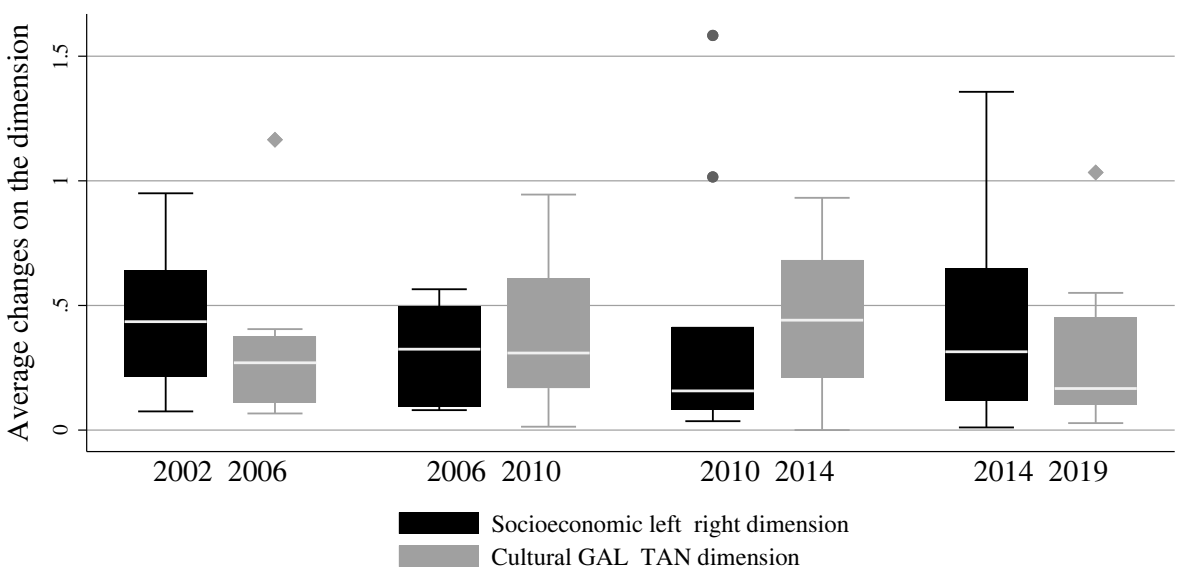

Fig. 1 Absolute change in policy positions of mainstream parties: 2002-2019. The figure shows the average change in the policy position of mainstream parties on the socioeconomic left-right $(0-10)$ and the GAL-TAN (0-10) dimensions between 2002 and 2019 in the 11 sample countries. (Data taken from the Chapel Hill Expert Survey Trend File 1999-2014 [Bakker et al. 2015; Polk et al. 2017], as well as the Chapel Hill Expert Survey 2019 [Bakker et al. 2020] (CHES))

a problem for the analysis at hand, as I am not interested in the determinants of voters' policy preferences but rather the policy positions of parties. Keeping this in mind, I follow previous contributions in locating EU and migration issues primarily on the GAL-TAN dimension (see, e.g., Kriesi et al. 2006; Marks and Wilson 2000).

Although the GAL-TAN dimension is similar to the classic socioeconomic dimension, empirical studies have shown that mainstream parties are rather unresponsive towards voters and rivalling parties on the GAL-TAN dimension (see, e.g., Mattila and Raunio 2012; van der Eijk and Franklin 2004). Following a basic premise of the cleavage theory, previous contributions argued that mainstream parties are programmatically inflexible regarding new issue dimensions, as mainstream parties are internally divided about these issues and face the threat of upsetting voters and members who, while sharing the party's policy position on the socioeconomic dimension, might object to its position on the GAL-TAN dimension (Hooghe and Marks 2018; Hobolt et al. 2009).

However, as described above, several European mainstream parties have changed their policy positions on the GAL-TAN dimension in recent years. To further illustrate the anecdotal evidence cited in the introduction of this paper, Fig. 1 shows a box plot of the average changes of mainstream parties' positions on the GAL-TAN dimension in absolute terms.

I use absolute terms to avoid positive and negative changes cancelling each other out. Between 2002 and 2006, mainstream parties on average changed their position on the GAL-TAN dimension (0-10) to a much lesser degree than on the socioeconomic dimension, with an average change of 0.06 points. Looking at the period between 2006 and 2019, this number nearly doubles, with average changes on the GAL-TAN dimension of 0.11 points. From the figure it follows that the median value of policy position changes also increased between 2006 and 2014, 
with a slight decrease between 2014 and 2019. Moreover, between 2006 and 2014 the policy position changes on the GAL-TAN dimension were greater than on the socioeconomic dimension. The interquartile range of changes on the GAL-TAN dimension also increased between 2006 and 2019. The figure further shows that there are some outliers in the sample.

These findings underpin the observation of increased movement on the GAL-TAN dimension made in the introduction, and they raise the question of how these position changes of mainstream parties on the new GAL-TAN dimension-which, according to the cleavage theory, should hardly exist—can be explained. In this paper, I argue that these changes can be explained through spatial models of electoral competition and the responsiveness of mainstream parties to the electoral success of RWPPs, as well as the ideological proximity to these parties.

\section{Mainstream Parties and the Other "Populist Zeitgeist"}

In the introduction of this paper, I stated that parties termed "populist" are seemingly on the rise in Europe. But, while being used vividly, "populism" is a rather elusive term that has been defined in various ways (see Hawkins 2009). In this paper, I follow Cas Mudde (2004, p. 543) and define populism as a thin ideology that considers society to be "separated into two homogeneous and antagonistic groups, 'the pure people' versus 'the corrupt elite', and which argues that politics should be an expression of the volonté générale (general will) of the people."

In his seminal contribution, Mudde (2004) has proclaimed the emergence of a "populist zeitgeist" by identifying traits of populist anti-elite rhetoric in the political discourse of mainstream parties. He argues that various mainstream opposition parties have challenged governing parties by using an anti-elite rhetoric (see also Mair 2007). In testing these arguments, Rooduijn et al. (2014) found that mainstream parties have not become more populist when faced with successful populist challengers. Although I agree with their finding, I argue that this is only half the picture since RWPPs are not only characterised by their anti-elite rhetoric but also by specific policy positions on the GAL-TAN dimension. Thus, the conclusion that mainstream parties are not chasing the "populist zeitgeist" might be premature, as the "populist zeitgeist" in Europe is not only coined by populism as a thin ideology but also by the host ideology of RWPPs. From this it follows that while mainstream parties may not be responsive towards the populist rhetoric, they might nonetheless chase the other "populist zeitgeist," which consists of the specific policy positions of European RWPPs on the GAL-TAN dimension.

By definition, right-wing populist parties take strong conservative and nationalist policy positions and emphasise traditional culture, national self-interest and identity, and authority, which are allegedly all under threat by a supposed group of "outsiders" and "the elite" (see Mudde and Kaltwasser 2013; Rydgren 2005; Taggart 2000). Right-wing populist parties combine these positions with newer topics such as climate protection, same-sex marriage, and the protection of a cultural status quo that is supposedly undermined by "the elite" (see Lockwood 2018; Pelinka 2013; Pappas et al. 2009). Thus, they position themselves against cosmopolitan values 
as well as multiculturalism and demand a return to traditional structures, making the GAL-TAN dimension their primary dimension of electoral competition (see Inglehart and Norris 2016).

Nonetheless, this is not to say that all RWPPs put the same weight on each individual GAL-TAN dimension issue. The salience of single issues in the political discourses of parties and the public can show considerable variation over time (see Ademmer et al. 2018; Braun and Schmitt 2020). But this variance makes it all the more necessary to move beyond the analysis of single issues and focus on the coherent policy positions taken by RWPPs.

Taking a strong coherent position on the GAL-TAN dimension is what distinguishes RWPPs from the old radical right-wing parties (see Kriesi 2010; Zaslove 2008). Unlike these parties, RWPPs move beyond the ownership of single-mostly migration-issues and challenge mainstream parties on the GAL-TAN dimension. ${ }^{2}$ This links RWPPs to specific policy positions and gives merit to shifting the analysis from the single-issue competition of radical right-wing parties to analysis of mainstream party responsiveness towards RWPPs on the GAL-TAN dimension in general. Irrespective of this, it is important to point out that populism and radical right-wing positions are strongly intertwined in Europe. This makes it difficult to isolate the individual effects on mainstream parties and increases the need for a theoretically founded combined consideration of populism and right-wing GAL-TAN positions.

Concerned with the policy positions of radical right-wing parties regarding single issues, Abou-Chadi and Krause (2020), Abou-Chadi (2016), Wagner and Meyer (2017), Han (2015), and van Spanje (2010) already found mainstream parties to be responsive to radical right-wing parties on migration and European integration issues. However, none of these studies assessed the impact of rivalling right-wing populist parties' success on the positions of mainstream parties on the GAL-TAN dimension. ${ }^{3}$ This is, however, necessary for assessing the unique electoral challenge that RWPPs pose. A notable exception is provided by Guiso et al. (2017), who found that the electoral success of populist parties is correlated with a reduction in distance between populist and nonpopulist parties regarding European integration and immigration issues.

Although making valid arguments and assumptions, Guiso et al. (2017) do not distinguish between left-wing and right-wing populism and the issues salient in the respective party discourses. In the context of electoral competition this distinction is important, as spatial proximity of parties is a crucial factor in the analysis of electoral competition (see Williams and Whitten 2015). In the following, I address this research gap by arguing why and how mainstream parties respond to the success of RWPPs on the GAL-TAN dimension and how this responsiveness is affected by ideological proximity to RWPPs.

\footnotetext{
2 This is not to say that some old right-wing populist parties might not also have become RWPPs by introducing populist rhetoric and taking positions on the GAL-TAN dimension (see Pelinka 2013).

3 The contribution of Abou-Chadi and Krause (2020) is especially noteworthy because it shows in a convincing way how radical right-wing challengers can pressure mainstream parties into policy position shifts. Note that some of the parties in the analysis of Abou-Chadi and Krause (2020) are also populist.
} 
But first it is necessary to discuss the importance of looking at right-wing populist parties. One could argue that it is sufficient to analyse radical right-wing parties, as the electoral competition is more about specific policy positions. However, the communication of these positions is a key component in the electoral success of RWPPs. As argued above, RWPPs do not address single issues, but take coherent policy positions on the GAL-TAN dimension. The depoliticisation of the GAL-TAN dimension has made mainstream parties less responsive towards (changing) preferences of the electorate, which has created a potential for its politicisation by populist parties that specifically address the failure of "the elites" to represent the "will of the people."

The uniqueness of the RWPP strategy can best be exemplified by looking at the issue of EU integration, which is frequently addressed by European RWPPs. Rightwing populist parties address EU integration from a policy position point of view by arguing that it undercuts national sovereignty and leads to the loss of cultural identity. Both of these issues are directly related to the GAL-TAN dimension. By advancing EU integration, RWPPs argue that "the elites" allegedly ignore the policy preferences of the electorate, i.e., the will of the people. Rejecting the EU is further closely connected to the populist rhetoric in itself because the EU can easily be framed as a project of the elites and the establishment that is profitable only to them and not to the "ordinary" people.

Because I argue that populism in itself plays an important role in challenging mainstream parties on the GAL-TAN dimension, it is important to discuss whether the concept of populism is really necessary to explain the mechanism at work. As argued by Rooduijn (2019), the main challenges to current populism research are

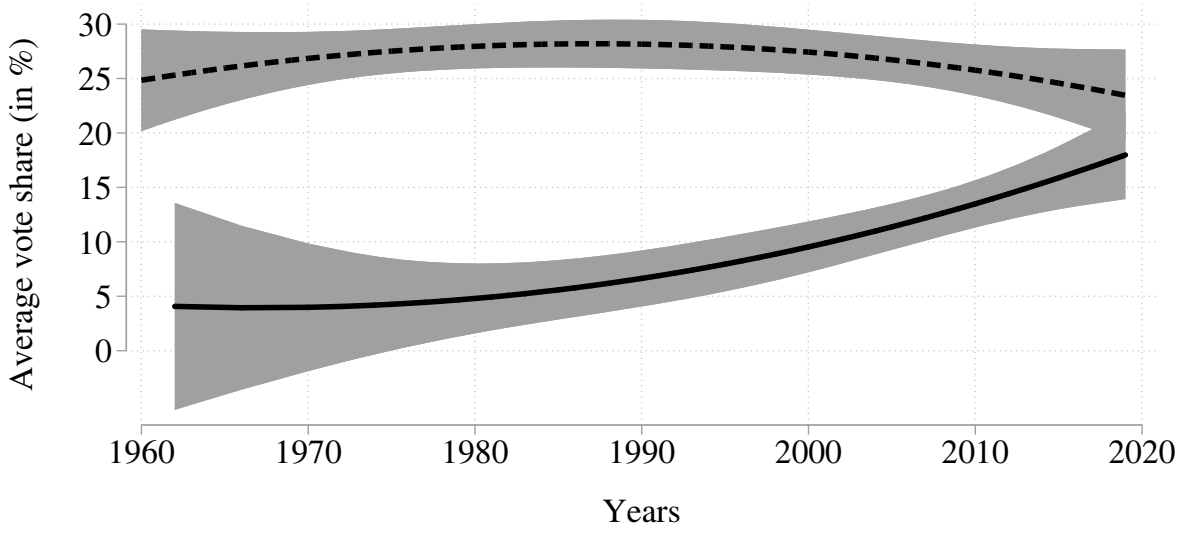

- Right wing populist parties

- Mainstream parties

Fig. 2 Vote share of right-wing populist parties: 1960-2019. The figure shows the average vote share of right-wing populist parties (solid black line) and the average vote share of mainstream parties (dashed line) in the 11 sample countries between 1960 and 2019, both with 95\% confidence intervals. The averages were plotted by using moving averages and fractional-polynomial prediction plots. (Data taken from the ParlGov dataset [Döring and Manow 2019]) 
conceptual overstretching and the detaching of populism research from adjacent fields. I argue that both challenges are met by the mechanism I propose.

First, I attribute the success of RWPPs and the possible response of mainstream parties to this success to the populist rhetoric that specifically picks up "the elite's" lack of responsiveness to the "will of the people" on the GAL-TAN dimension. Second, I combine the analysis of populism with the adjacent field of electoral competition by arguing that recent policy position changes of mainstream parties on the GAL-TAN dimension can be explained by not only taking into account the policy positions of challenger parties but also by accounting for the rhetoric by which these positions are communicated in the electoral strategy.

Taking coherent right-wing policy positions with a populist rhetoric in combination with the lack of responsiveness of mainstream parties on the GAL-TAN dimension has arguably contributed to the electoral success of RWPPs in recent years. In order to examine this electoral success of RWPPs, Fig. 2 shows the average vote share of RWPPs and mainstream parties between 1960 and 2019 in the 11 European sample countries. The figure shows that between 2002 and 2019, RWPPs have, on average, increased their vote share by 8 percentage points, while mainstream parties have lost around 5 percentage points.

Spatial models of electoral competition suggest that mainstream parties will overcome their inflexibility and change their positions if rivalling parties become increasingly successful (see, e.g., Budge 1994; Harmel and Janda 1994; Meguid 2005). Against this backdrop, I argue that the recent success of RWPPs will trigger a response by mainstream parties on the GAL-TAN dimension. As the previous section has shown, mainstream parties indeed display increased movement on the GAL-TAN dimension. The question, however, is whether this is the case because mainstream parties position themselves in opposition to the policy positions of rivalling RWPPs or adapt a similar position (see Meguid 2005).

I argue that, for two reasons, mainstream parties are more likely to choose an accommodative strategy against RWPPs. First, the electoral success of RWPPs is built on their issue ownership on the GAL-TAN dimension (Arzheimer and Berning 2019). Hence, not engaging them on the GAL-TAN issues will not decrease their support. Second, as mainstream parties will be concerned with gaining back voters they lost to RWPPs, they will, in line with spatial theory, challenge these rival parties directly (van Spanje and de Graaf 2018). Other contributions have shown that this strategy can prevent niche party success on single issues (Pardos-Prado 2015) or at least impact the socioeconomic policy positions (see Krause and Giebler 2020).

With a focus on recent European elections, Downes and Loveless (2018) were able to show that some nonincumbent mainstream parties electorally outperformed RWPPs by emphasising immigration issues but only in response to the electoral threat posed by RWPPs. This is in line with the consideration that mainstream parties might adapt the policy positions of RWPPs to regain or maintain their vote share when an RWPP becomes successful (see Mudde 2013, 2007). Thus, if an RWPP becomes successful, mainstream parties are expected to shift their policy positions closer towards this party's position. Based on these considerations, I derived the following hypothesis: 
Table 1 GAL-TAN policy positions of mainstream parties: 2002-2019. (Data taken from the Chapel Hill Expert Survey Trend-File 1999-2014 [Bakker et al. 2015; Polk et al. 2017] and the Chapel Hill Expert Survey 2019 [Bakker et al. 2020] (CHES))

\begin{tabular}{lllll}
\hline Party type & Mean & SD & Obs & Distance \\
\hline Conservative & 6.65 & 0.78 & 36 & 1.84 \\
Liberal & 4.97 & 1.35 & 20 & 3.13 \\
Socialist & 3.63 & 0.80 & 44 & 4.88 \\
\hline
\end{tabular}

SD standard deviation, Obs observations

Hypothesis 1 The greater the electoral success of an RWPP, the closer a mainstream party will move towards this party's position on the GAL-TAN dimension.

As argued above, it is likely that specific party characteristics and the location of mainstream parties in the policy space will affect the responsiveness towards the electoral success of RWPPs. Previous contributions have shown that ideological proximity plays an important role in the responsiveness of parties towards rival parties (see, e.g., Williams and Whitten 2015). This is the case because a party's vote share predominantly depends on the policy position of the rival party closest to its own position (see Adams 2001). To investigate the proximity in detail, Table 1 shows the average policy positions of mainstream parties by party family and pits them against their distance to rivalling RWPPs on the GAL-TAN dimension.

Two main findings can be derived from the table. First, the table shows that conservative mainstream parties are-on average-positioned closer to the TAN pole than any other mainstream party. Second, the average policy position distance of conservative mainstream parties to rivalling RWPPs is, with 1.84 points, much closer than the average position distance of liberal or socialist mainstream parties to RWPPs. In fact, in all sample countries with a conservative mainstream party, this conservative party is the closest party to the rivalling RWPP. ${ }^{4}$ Thus, in line with the arguments on spatial electoral competition from Meguid (2005), RWPPs will especially compete with conservative parties in the electoral competition. This leads to an increased responsiveness of conservative mainstream parties (see Mudde 2013). Based on this, I hypothesised the following:

Hypothesis 2 Conservative mainstream parties are more responsive towards the electoral success of RWPPs than mainstream parties of other party families.

In sum, I argue that the observed position changes of mainstream parties on the GAL-TAN dimension can be explained by the electoral success of RWPPs. Based on arguments derived from the spatial theory of electoral competition, I expect mainstream parties to reduce the distance to RWPPs once these parties become successful. Conservative mainstream parties are thereby expected to be especially responsive due to their ideological proximity.

\footnotetext{
${ }^{4}$ Denmark and Finland have no conservative mainstream party. I account for this in the robustness checks by coding the nonconservative party closest to the rivalling RWPP as the closest contender.
} 


\section{Operationalisation and Data}

To test the hypotheses, I used a time-series, cross-sectional dataset that includes national mainstream parties between 2002 and 2019 from 11 European sample countries that have at least one RWPP. ${ }^{5}$ This restriction to Western European countries is necessary because the shape of the cultural GAL-TAN dimension arguably differs between Western and Eastern Europe, inducing possible biases (see de Vries 2013). The period of analysis was chosen because of data limitations. The unit of analysis is the change in a mainstream party's policy position distance to a rivalling RWPP between the respective Chapel Hill Expert Survey (CHES) years.

The employed identification strategy of RWPPs was twofold. First, I based the identification of populist parties on the PopuList by Rooduijn et al. (2019). Second, I used the CHES to identify the GAL-TAN policy position. A populist party is coded as right-wing if its average position on the GAL-TAN dimension is one standard deviation above the average GAL-TAN position of other parties in the respective country. I also cross-checked this coding with the far-right coding by Rooduijn et al. (2019), showing that not all RWPPs in my sample were also radical rightwing parties. This underscores the previous argument that there is a difference in analysing radical right-wing parties and right-wing populist parties. Furthermore, all but three RWPPs identified are also coded as Eurosceptic parties by Rooduijn et al. (2019). Based on this, 26 RWPPs were identified (see online appendix, Table A 1). ${ }^{6}$ Note that not all identified RWPPs have competed in all elections.

The vote share of the RWPPs was taken from the CHES. I calculated the change by subtracting the vote share provided by a previous CHES from the one in the subsequent CHES. The vote share in the CHES always refers to the last national election. If an RWPP competes for the first time, the previous vote share is 0 . If no election took place between two CHES waves, the change is also 0. The variables were distributed normally (see online appendix, Fig. A 1).

The coding of mainstream parties was based on the data provided by the CHES (1999-2019) and the ParlGov dataset by Döring and Manow (2019). A party was coded as mainstream if it belongs to either the socialist, conservative, or liberal party family and is frequently the majority party in a government coalition or on average wins a considerable number of votes. The latter was defined as an average vote share of one standard deviation above the country average. Based on this, 25 mainstream parties were identified (see online appendix, Table A 2). ${ }^{7}$ All identified mainstream parties competed in all the elections.

\footnotetext{
5 The 11 sample countries included in the analysis are Austria, Belgium, Denmark, Finland, France, Germany, Greece, Italy, the Netherlands, Sweden, and the United Kingdom.

6 Compared with that of Abou-Chadi and Krause (2020), my coding overlaps in eight instances with the 40 parties they include in their analysis. Although this result also stems from differences in the chosen sample countries and time frame, it also stems from differences in the classification of parties. For example, the BZO is coded as RWPP in my sample but not as radical right-wing party in the sample by Abou-Chadi and Krause (2020), and the MSI is rightly coded as radical right-wing but not as populist.

7 Based on this coding approach, the Italian Forza Italia (FI/PdL) would also be coded as a mainstream party. As this party is already coded as RWPP, the party is not included as a mainstream party. I control for this coding decision in the course of the robustness checks.
} 
The change in policy-position distance between mainstream parties and RWPPs on the GAL-TAN was measured using the CHES. Using the change in position distance is important because the question is whether changes in the electoral success of RWPPs are correlated with a reduction in the position distance between RWPPs and mainstream parties. Since conservative mainstream parties are positioned closer to RWPPs, only this approach makes it possible to go beyond the mere correlation between party family and policy position distance to RWPPs.

I used the CHES position coding because the GAL-TAN dimension in the CHES is congruent to my conceptualization of the GAL-TAN dimension (see Polk et al. 2017). Other sources do not provide such an indexed GAL-TAN policy position of parties. Although a position scale could be constructed (see Wagner and Meyer 2017), I followed Meijers (2017) and based the coding on the CHES data. I deliberately did not calculate the position changes of mainstream parties in relation to the extreme ends of the scale because that was not in line with models of spatial competition (see Adams 2001). The distance was calculated by subtracting the position of a given mainstream party from that of the rivalling RWPP and calculating the change in distance between $\mathrm{t}-1$ and $\mathrm{t}$. Positive values indicate that the distance between a mainstream party and an RWPP increases, while negative values indicate that the distance is decreasing. In the cases with more than one RWPP, I used the mean position of the RWPPs to calculate the distance to the RWPP platform. The values were distributed normally (see online appendix, Fig. A 2).

Theoretically, the value of this variable can also become negative when an RWPP moves closer to the mainstream parties' policy positions. Hence, it is important to note that, while theoretically possible, RWPPs on average do not move closer to mainstream parties but, if anything, on average shift 0.08 points towards the TAN pole of the GAL-TAN dimension.

As control variables, I included the change in the mean policy preference of voters regarding migration and EU integration (see Adams and Somer-Topcu 2009). The preferences were based on the European Social Survey (ESS) data (ESS 2018, 2014, $2010,2006,2002) .{ }^{8}$ In the course of the robustness checks I also combined both variables into one measure to approach a singular measure of the GAL-TAN policy preference change of the electorate. In the few cases of missing data, I used linear interpolation. Additionally, I also controlled for the influence of mainstream party vote loss as well as government participation by mainstream parties and RWPPs (see Somer-Topcu 2009). I accounted for the previous vote loss with a variable that gives the vote loss of a mainstream party between $\mathrm{t}-1$ and $\mathrm{t}$. Furthermore, I included a variable that controls for the first time an RWPP competes in an election. Finally, I controlled for the position shifts of nonmainstream, nonpopulist parties by including the mean policy position shift of these other parties between $\mathrm{t}-1$ and $\mathrm{t}$.

Because the dependent and independent variable showed a normal distribution, I ran ordinary least squares regressions to assess the correlation between a change

\footnotetext{
8 Specifically, the ESS asked the respondents, "Is [country] made a worse or a better place to live by people coming to live here from other countries?" and "Now thinking about the European Union, some say European unification should go further. Others say it has already gone too far. Using this card, what number on the scale $(0-10)$ best describes your position?"
} 
in the RWPP vote share and the change in the policy-position distance between an RWPP and a mainstream party. To test the hypotheses, I modelled an interaction term that addressed the expectation that conservative mainstream parties would show higher responsiveness to the electoral success of RWPPs than other mainstream parties.

A common problem in panel data that often leads to misspecification is autocorrelation. This, however, would be an issue only if one would use the absolute policyposition distance on the GAL-TAN dimension at $t$ and not the change between $t$ and $\mathrm{t}-1$. I employed robust standard errors to account for heteroscedasticity (see White 1980). My baseline model is defined by the following:

$$
\Delta D_{c, t}^{m}=\Delta V S_{c, t}^{p} \cdot \operatorname{ConsM}_{c, t}+\Delta V S_{c, t}^{p}+\operatorname{ConsM}_{c, t}+\beta X_{j, t}+\mu_{m}+\gamma_{c}+\lambda_{t}+\varepsilon,
$$

where $\Delta D_{c, t}^{m}$ is the change in distance $(\Delta D)$ between a mainstream party $(m)$ and an RWPP in a country $(c)$ between $\mathrm{t}-1$ and $\mathrm{t}(t)$. The interaction term of the independent variable is given by $\Delta V S_{c, t}^{p} \cdot \operatorname{ConsM}_{c, t}$, with $\Delta V S$ being the change in the RWPP $(p)$ vote share $(V S)$ in interaction with conservative mainstream parties (Cons $M$ ) responding to this change between $\mathrm{t}-1$ and $\mathrm{t}(t)$ in a country $(c)$. With $X_{j, t}$ a vector of the described control variables $(j)$ is included. Furthermore, terms denoting mainstream party $\left(\mu_{m}\right)$, country $\left(\gamma_{c}\right)$, and time $\left(\lambda_{t}\right)$ fixed effects were incorporated.

\section{Results}

The regression analyses in Table 2 focus on the main variables and the interaction term. The control variables are introduced in a second step in Table 3 after the effect of the interaction term is addressed. Model 1 reports the coefficient of the RWPP vote-share change variable without any fixed effects. The coefficient of the variable is, at -0.024 , negative but not statistically significant. Models 2-4 also include only the RWPP vote-share change variable but with different combinations of year, party, and country fixed effects. The change in fixed effects does not change the size or nonsignificance of the coefficient.

The interaction term for conservative mainstream parties is introduced in model 5. The term is, at -0.088 , negative and statistically significant. In models $6-8$, year, party, and country fixed effects are introduced. The size and statistical significance of the interaction term's coefficient remain stable across these models. The RWPP vote-share change variable and the dummy variable for conservative mainstream parties remain nonsignificant. From this it follows that the correlation between the RWPP vote-share increase and the decrease in distance to these RWPPs on the GAL-TAN is statistically significant only for conservative mainstream parties. For nonconservative mainstream parties, the coefficient is very small and nonsignificant.

To address the substantial relevance of the estimated coefficients, I calculated the effect size, ceteris paribus, of a 1 -standard deviation (6.9 percentage points) increase in an RWPP's vote share on the distance reduction of a conservative and nonconservative mainstream party. The marginal effects were calculated based on 
Table 2 Mainstream party responsiveness to right-wing populist parties with and without interaction term

\begin{tabular}{|c|c|c|c|c|c|c|c|c|}
\hline & (1) & (2) & (3) & (4) & (5) & (6) & (7) & (8) \\
\hline $\begin{array}{l}\text { RWPP VS } \\
\Delta\end{array}$ & $\begin{array}{l}-0.024 \\
(0.02)\end{array}$ & $\begin{array}{l}-0.022 \\
(0.02)\end{array}$ & $\begin{array}{l}-0.031 \\
(0.02)\end{array}$ & $\begin{array}{l}-0.031 \\
(0.02)\end{array}$ & $\begin{array}{l}-0.001 \\
(0.02)\end{array}$ & $\begin{array}{l}0.002 \\
(0.02)\end{array}$ & $\begin{array}{l}-0.007 \\
(0.02)\end{array}$ & $\begin{array}{l}-0.008 \\
(0.02)\end{array}$ \\
\hline $\begin{array}{l}\text { RWPP VS } \\
\Delta * \text { ConsM }\end{array}$ & - & - & - & - & $\begin{array}{l}-0.088^{* *} \\
(0.03)\end{array}$ & $\begin{array}{l}-0.087 * * \\
(0.03)\end{array}$ & $\begin{array}{l}-0.089 * * \\
(0.04)\end{array}$ & $\begin{array}{l}-0.086 * * * \\
(0.03)\end{array}$ \\
\hline $\begin{array}{l}\text { ConsM } \\
\text { dummy }\end{array}$ & - & - & - & - & $\begin{array}{l}-0.173 \\
(0.27)\end{array}$ & $\begin{array}{l}-0.176 \\
(0.25)\end{array}$ & $\begin{array}{l}0.399 \\
(1.45)\end{array}$ & $\begin{array}{l}-0.113 \\
(0.30)\end{array}$ \\
\hline Constant & $\begin{array}{l}0.140 \\
(0.13)\end{array}$ & $\begin{array}{l}0.039 \\
(0.31)\end{array}$ & $\begin{array}{l}-0.068 \\
(0.84)\end{array}$ & $\begin{array}{l}0.102 \\
(0.40)\end{array}$ & $\begin{array}{l}0.204 \\
(0.15)\end{array}$ & $\begin{array}{l}0.120 \\
(0.31)\end{array}$ & $\begin{array}{l}-0.072 \\
(0.82)\end{array}$ & $\begin{array}{l}0.197 \\
(0.47)\end{array}$ \\
\hline $\begin{array}{l}\text { Year fixed } \\
\text { effects }\end{array}$ & - & $\checkmark$ & $\checkmark$ & $\checkmark$ & - & $\checkmark$ & $\checkmark$ & $\checkmark$ \\
\hline $\begin{array}{l}\text { Party fixed } \\
\text { effects }\end{array}$ & - & - & $\checkmark$ & - & - & - & $\checkmark$ & - \\
\hline $\begin{array}{l}\text { Country } \\
\text { fixed effects }\end{array}$ & - & - & - & $\checkmark$ & - & - & - & $\checkmark$ \\
\hline Sample size & 83 & 83 & 83 & 83 & 83 & 83 & 83 & 83 \\
\hline $\mathrm{R}^{2}$ & 0.02 & 0.09 & 0.26 & 0.23 & 0.09 & 0.15 & 0.30 & 0.28 \\
\hline
\end{tabular}

Robust standard errors in parentheses

Significance levels: *** $p<0.01, * * p<0.05, * p<0.10$

model 8. Using model 8 for the calculations, if the vote share of an RWPP increases by 1 standard deviation, the distance between a conservative mainstream party and an RWPP is reduced by 0.5 standard deviation ( 0.59 points) on the GAL-TAN dimension. Compared to this, a 1-standard deviation increase in the RWPP vote share is only correlated with a 0.05 -standard deviation (0.06 points) decrease in the nonconservative mainstream party distance. This result for conservative mainstream parties is quite substantial because mainstream parties, on average, only changed their position on the GAL-TAN dimension between 2002 and 2019 by 0.10 points, with a standard deviation of 1.18 .

To illustrate this finding further, Fig. 3 plots the marginal effects for both groups based on model 7 and model 8 . The figure shows the estimated marginal effects between the 1st and 99th percentiles of the distribution of the independent variable. The figure shows that an increase in the RWPP vote share is not correlated with a decrease in the distance between mainstream parties and RWPPs on the GAL-TAN dimension in general, but it is strongly correlated with a decrease in distance between conservative mainstream parties and RWPPs. In sum, these findings do not back the first hypothesis but strongly support the second hypothesis.

Since the previous regression analyses focused only on the main variables and the interaction term for conservative mainstream parties in isolation, the second set of regression analyses introduced several control variables. The purpose of these additional regression models was to analyse whether the small and nonsignificant effect found for other mainstream parties and the strong and substantial effect found for conservative mainstream parties is robust against different control variables. The results are displayed in Table 3 . Note that the number of observations in the analysis is reduced by eight due to missing policy preferences of the electorate. 
Table 3 Mainstream party responsiveness to right-wing populist parties and control variables

\begin{tabular}{|c|c|c|c|c|c|c|c|c|}
\hline & (1) & (2) & (3) & (4) & (5) & (6) & (7) & (8) \\
\hline $\begin{array}{l}\text { RWPP VS } \\
\Delta\end{array}$ & $\begin{array}{l}-0.002 \\
(0.02)\end{array}$ & $\begin{array}{l}-0.003 \\
(0.02)\end{array}$ & $\begin{array}{l}-0.007 \\
(0.02)\end{array}$ & $\begin{array}{l}-0.008 \\
(0.02)\end{array}$ & $\begin{array}{l}-0.008 \\
(0.02)\end{array}$ & $\begin{array}{l}-0.009 \\
(0.02)\end{array}$ & $\begin{array}{l}-0.007 \\
(0.02)\end{array}$ & $\begin{array}{l}-0.008 \\
(0.02)\end{array}$ \\
\hline $\begin{array}{l}\text { RWPP VS } \\
\Delta * \text { ConsM }\end{array}$ & $\begin{array}{l}-0.086^{* *} \\
(0.04)\end{array}$ & $\begin{array}{l}-0.083 * * \\
(0.04)\end{array}$ & $\begin{array}{l}-0.087 * * \\
(0.04)\end{array}$ & $\begin{array}{l}-0.085^{* *} \\
(0.04)\end{array}$ & $\begin{array}{l}-0.092 * * \\
(0.04)\end{array}$ & $\begin{array}{l}-0.088 * * \\
(0.04)\end{array}$ & $\begin{array}{l}-0.093 * * \\
(0.05)\end{array}$ & $\begin{array}{l}-0.090 \text { ** } \\
(0.04)\end{array}$ \\
\hline $\begin{array}{l}\text { ConsM } \\
\text { dummy }\end{array}$ & $\begin{array}{l}0.293 \\
(1.15)\end{array}$ & $\begin{array}{l}-0.113 \\
(0.32)\end{array}$ & $\begin{array}{l}0.422 \\
(1.44)\end{array}$ & $\begin{array}{l}-0.119 \\
(0.31)\end{array}$ & $\begin{array}{l}0.311 \\
(1.47)\end{array}$ & $\begin{array}{l}-0.110 \\
(0.30)\end{array}$ & $\begin{array}{l}0.342 \\
(1.45)\end{array}$ & $\begin{array}{l}-0.112 \\
(0.31)\end{array}$ \\
\hline $\begin{array}{l}\text { Voter im- } \\
\text { migration } \\
\Delta\end{array}$ & $\begin{array}{l}-1.537 \\
(2.02)\end{array}$ & $\begin{array}{l}-1.525 \\
(1.87)\end{array}$ & - & - & - & - & - & - \\
\hline $\begin{array}{l}\text { Voter EU } \\
\text { integration } \\
\Delta\end{array}$ & $\begin{array}{l}0.274 \\
(2.40)\end{array}$ & $\begin{array}{l}0.247 \\
(2.11)\end{array}$ & - & - & - & - & - & - \\
\hline $\begin{array}{l}\text { Other party } \\
\text { position } \Delta\end{array}$ & $\begin{array}{l}0.074 \\
(0.09)\end{array}$ & $\begin{array}{l}0.075 \\
(0.08)\end{array}$ & - & - & - & - & - & - \\
\hline $\begin{array}{l}\text { Neg. party } \\
\text { vote share } \\
\Delta\end{array}$ & - & - & $\begin{array}{l}0.003 \\
(0.05)\end{array}$ & $\begin{array}{l}0.003 \\
(0.04)\end{array}$ & - & - & $\begin{array}{l}0.001 \\
(0.05)\end{array}$ & $\begin{array}{l}0.001 \\
(0.04)\end{array}$ \\
\hline Gov. $(\mathrm{t}-1)$ & - & - & $\begin{array}{l}0.095 \\
(0.31)\end{array}$ & $\begin{array}{l}0.135 \\
(0.28)\end{array}$ & - & - & $\begin{array}{l}0.120 \\
(0.31)\end{array}$ & $\begin{array}{l}0.153 \\
(0.29)\end{array}$ \\
\hline $\begin{array}{l}\text { Pop. gov. } \\
(\mathrm{t}-1)\end{array}$ & - & - & - & - & $\begin{array}{l}0.043 \\
(0.74)\end{array}$ & $\begin{array}{l}0.023 \\
(0.67)\end{array}$ & $\begin{array}{l}0.098 \\
(0.78)\end{array}$ & $\begin{array}{l}0.098 \\
(0.71)\end{array}$ \\
\hline First pop. & - & - & - & - & $\begin{array}{l}-0.184 \\
(0.34)\end{array}$ & $\begin{array}{l}-0.182 \\
(0.30)\end{array}$ & $\begin{array}{l}-0.195 \\
(0.34)\end{array}$ & $\begin{array}{l}-0.196 \\
(0.30)\end{array}$ \\
\hline Constant & $\begin{array}{l}-0.133 \\
(0.86)\end{array}$ & $\begin{array}{l}0.110 \\
(0.58)\end{array}$ & $\begin{array}{l}-0.131 \\
(0.81)\end{array}$ & $\begin{array}{l}0.114 \\
(0.49)\end{array}$ & $\begin{array}{l}0.003 \\
(0.81)\end{array}$ & $\begin{array}{l}0.263 \\
(0.68)\end{array}$ & $\begin{array}{l}-0.072 \\
(0.80)\end{array}$ & $\begin{array}{l}0.131 \\
(0.75)\end{array}$ \\
\hline $\begin{array}{l}\text { Year fixed } \\
\text { effects }\end{array}$ & $\checkmark$ & $\checkmark$ & $\checkmark$ & $\checkmark$ & $\checkmark$ & $\checkmark$ & $\checkmark$ & $\checkmark$ \\
\hline $\begin{array}{l}\text { Party fixed } \\
\text { effects }\end{array}$ & $\checkmark$ & - & $\checkmark$ & - & $\checkmark$ & - & $\checkmark$ & - \\
\hline $\begin{array}{l}\text { Country } \\
\text { fixed effects }\end{array}$ & - & $\checkmark$ & - & $\checkmark$ & - & $\checkmark$ & - & $\checkmark$ \\
\hline Sample size & 75 & 75 & 83 & 83 & 83 & 83 & 83 & 83 \\
\hline $\mathrm{R}^{2}$ & 0.38 & 0.35 & 0.31 & 0.28 & 0.31 & 0.28 & 0.31 & 0.29 \\
\hline
\end{tabular}

Robust standard errors in parentheses

Gov. government, Pop. populist

Significance levels: *** $p<0.01, * * p<0.05, * p<0.10$

While all models use year fixed effects, the models switch between party and country fixed effects. Using year and party fixed effects, model 1 introduces the two variables that control for the policy preference changes of the electorate as well as for the policy position shifts of other parties. Model 2 uses the same control variables but changes from party to country fixed effects. The coefficient of the RWPP voteshare change variable is small and nonsignificant in both models, whereas the interaction term for conservative mainstream parties is, at -0.086 and -0.083 , statistically significant. Both results support the previous findings.

Models 3 and 4 include the variable that measures vote loss of mainstream parties as well as the variable that controls for government participation. Including 
both variables does not change statistical (non)significance of the RWPP vote-share change variable or the interaction term but slightly increases the coefficient of the interaction term to -0.087 and -0.085 , respectively. In the next two models, the significance of the coefficients is also not affected by the variables that control for government participation of an RWPP or for the first time an RWPP competes in an election. However, the coefficient of the interaction term is again slightly increased to -0.092 and -0.088 , respectively. Model 7 and model 8 keep the previous control variables and reintroduce the variables that control for government participation and vote losses by mainstream parties, again marginally increasing the size of the interaction term's coefficient to -0.093 and -0.090 , respectively.

Overall, the coefficient of the RWPP vote-share change variable as well as the interaction term for conservative mainstream parties proved to be robust in size and statistically significant across the models. This finding strongly supports the previous results.

To interpret the coefficients in substantial terms, I again calculated the effect size, ceteris paribus, of a 1-standard deviation (6.9 percentage points) increase in an RWPP's vote share on the distance between the RWPP and mainstream as well as conservative mainstream parties. I again calculated the marginal effects based on model 8 . If the vote share of an RWPP increases by 1 standard deviation, the distance between the conservative mainstream party and the RWPP is reduced by 0.5 standard deviation ( 0.62 points). Reconsidering that the average distance between RWPPs and conservative mainstream parties on the GAL-TAN dimension is 1.84 points, a $1-$ standard deviation increase in the RWPP vote share correlates with

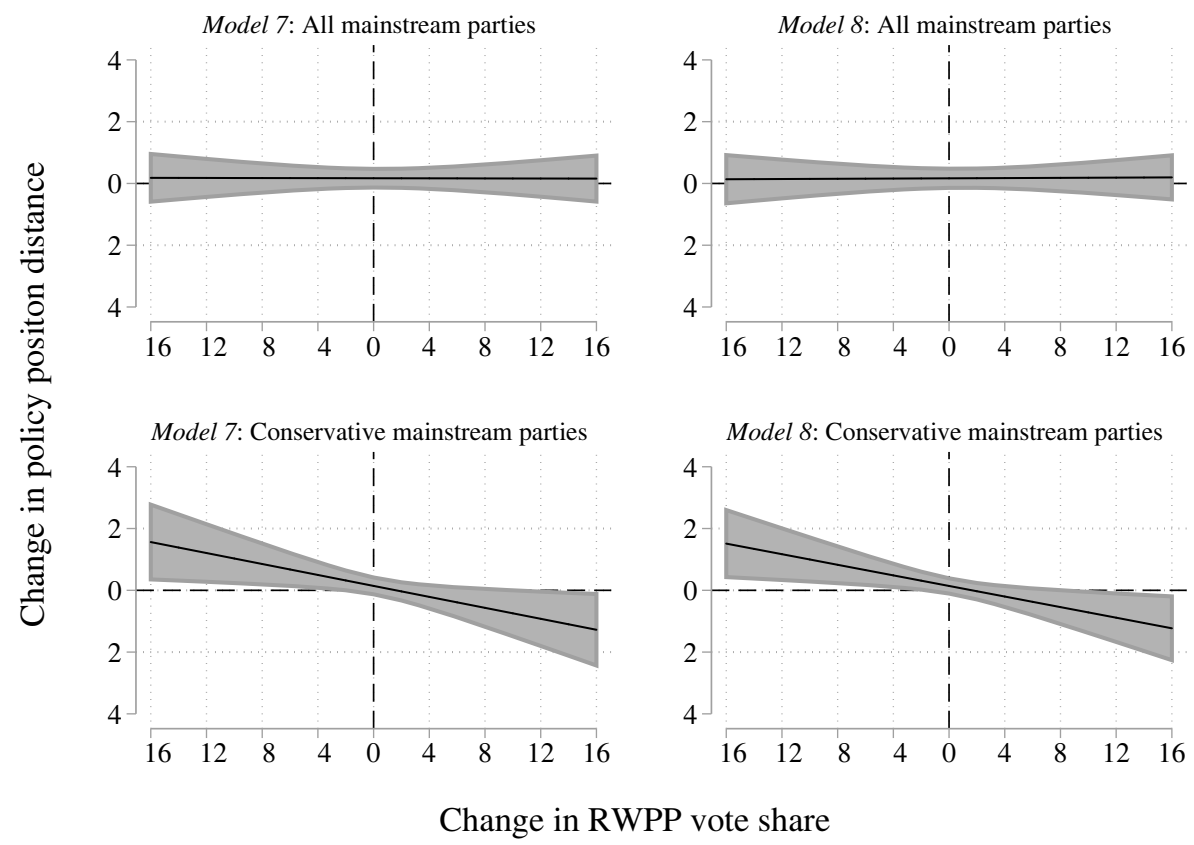

Fig. 3 Marginal effects: mainstream party responsiveness to right-wing populist parties. (Calculation based on the regression analysis displayed in Table 2) 


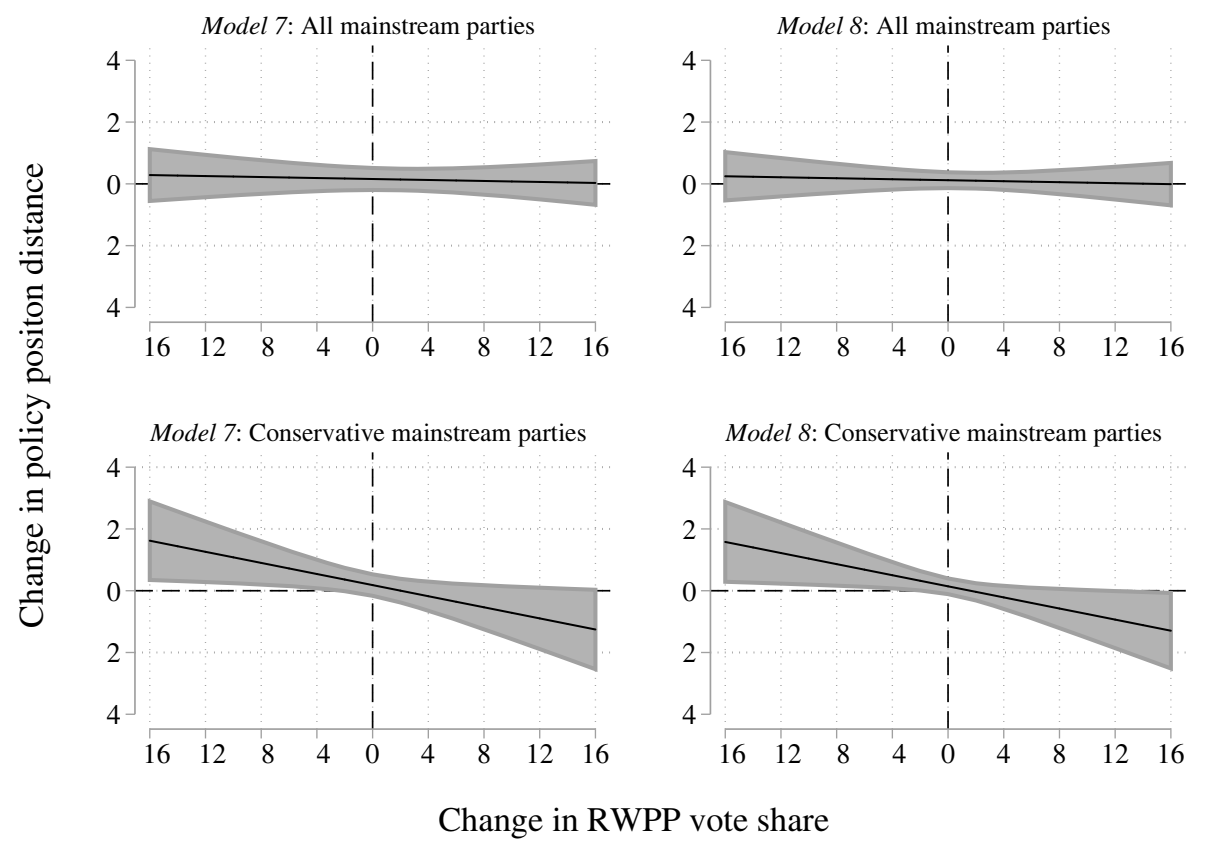

Fig. 4 Marginal effects: mainstream party responsiveness to right-wing populist parties with control variables. (Calculation based on the regression analysis displayed in Table 3)

a distance reduction between an RWPP and a conservative mainstream party of about $35 \%$. In comparison, a 1-standard deviation (6.9 percentage points) increase in an RWPP's vote share is again only correlated with a distance reduction of 0.05 standard deviation ( 0.06 points). The weak correlation in the case of mainstream parties in general is again not statistically significant.

To further illustrate the correlation, Fig. 4 plots the marginal effects for both groups based on model 7 and model 8 . The figure again shows that an increase in the RWPP vote share is not correlated with a decrease in the distance between mainstream parties and an RWPP on the GAL-TAN dimension in general, but it is strongly correlated with a decrease in distance between conservative mainstream parties and RWPPs.

In sum, the findings strongly support the second hypothesis, according to which conservative mainstream parties are expected to be especially responsive to the voteshare increase of RWPPs. Additionally, the lack of robust statistical significance in the case of mainstream parties in general leads me to conclude that the same correlation cannot be assumed for this group of parties. Although the first hypothesis on the expected correlation for mainstream parties in general is not support by the analysis, the second hypothesis on the increased responsiveness of conservative mainstream parties is strongly supported. 


\section{Robustness of Results}

Since the dependent and independent variable are measured in the same time period, the analysis cannot rule out reversed causality. One could argue that the distance reduction by mainstream parties draws attention to RWPPs and thereby increases their vote share. However, this would mean that mainstream parties change their positions without any reason. The only pressure that could trigger this behaviour is changes in the preference of voters. But, as I showed, these changes are not correlated with the dependent or independent variable in the analysis. From this it follows that there is no theoretical reason why mainstream parties should accommodate the positions of RWPPs prior to their electoral success (see Meguid 2005).

Further, it is possible that RWPPs move towards the TAN pole while conservative parties move in the same direction, leading to a distance change of 0 . In this scenario, the conservative mainstream party nonetheless accommodated the RWPPs' policy position. Although theoretically possible, this works against the employed hypotheses tests by - if anything-underestimating the strength of the correlation between vote-share increase and distance reduction.

To empirically rule out the possibility that RWPPs increase their vote share if mainstream parties close the distance to them, I calculated the correlation between mainstream party position distance and RWPP vote share (see online appendix, Table A 3). Because of possible issues of autocorrelation, I additionally calculated Prais-Winsten regressions (Prais and Winsten 1954). The analysis shows that there is no statistically significant correlation between the policy position distance of mainstream parties to RWPPs and the electoral success of RWPPs. Hence, the theoretical arguments and empirical results support the direction of causality I propose.

To further assess the robustness of the results, additional regression models were calculated (see online appendix, Table A 4). Model 1 uses fixed-effects regression controlling for both individual parties and countries in the model. The second and third models are also fixed-effects regression models, with model 2 clustering the standard errors by parties and model 3 clustering the standard errors by countries. The last fixed-effects regression is employed in model 4. The model is additionally jack-knifed.

The remaining four models use different operationalizations of variables and exclude a critical case. Model 5 is not based on coding conservative mainstream parties but rather on the mainstream party closest to the respective RWPP. The model shows a negative and statistically significant coefficient of the interaction term. The size of the coefficient is slightly smaller than in the case of conservative mainstream parties. Hence, my results on party responsiveness are not driven by coding conservative mainstream parties as the closest competitor.

Model 6 uses a different operationalization of the voters' policy preference change by combining the EU integration and migration preferences into a single measure. The same control variable is also included in model 7, with additional control variables. The last model excludes Italy because the coding of some parties in Italy is problematic, with the FI/PdI party being an RWPP mainstream party, no additional conservative or liberal mainstream party competing in elections, and the M5S party 
sometimes being coded as RWPP. In sum, the coefficients of the main variables of interest are robust against the different model specifications in every case.

\section{Conclusion}

In this paper I addressed the research question of why several European mainstream parties changed their policy positions on the GAL-TAN dimension in recent years. In answering this question, I argued that mainstream parties changed their positions on the GAL-TAN dimension in response to the electoral success of RWPPs. This success pressures mainstream parties into closing in on the positions of rivalling RWPPs. Due to the ideological proximity, I argued that first-and-foremost conservative mainstream parties will close the distance to RWPPs. Supported by the empirical evidence, the answer to the research question is that the between-country variation can be explained by the variance in RWPP success, while the within-country variation is explained by the almost exclusive responsiveness of conservative mainstream parties.

One limitation of this finding, however, is the narrowness of the empirical analysis due to the short period of analysis. This bears the risk of missing long-term dynamics and developments, since mainstream parties might only move back to a previous position at the TAN pole from which the party had moved away in previous years. Finally, it is also important to stress that the empirical support of my theoretical arguments stems purely from correlation. The statistical analysis employed is not a causal identification strategy.

Having this in mind, the paper provides several connection points for future research. Because I only focused on RWPPs and the GAL-TAN dimension, the findings only hold in this context. Mainstream parties might react differently to leftwing populist parties or to RWPPs on the socioeconomic dimension (see Schumacher and van Kersbergen 2016). Because of the restriction of the analysis to Western European countries, the external validity of the findings holds only for these countries. Thus, a separate analysis is necessary to encompass the specific patterns of the GAL-TAN dimension in Eastern Europe. Such an analysis could be conducted by using the Manifesto Project dataset (see Volkens et al. 2020), with which the geographic and temporal scope of the analysis can be extended. It is also necessary to further investigate the arguments put forward regarding issue ownership of RWPPs on the GAL-TAN dimension. It is also crucial to assess whether chasing the "populist zeitgeist" is an effective measure against RWPPs. So far, this strategy has produced mixed results and is highly dependent on specific factors (see Meijers and Williams 2020; van Spanje and de Graaf 2018; van Spanje and van der Brug 2009). Thus, the strategy of chasing the "populist zeitgeist" might eventually result only in legitimising the nationalist, illiberal, and xenophobic policy positions of RWPPs (see Meguid 2005).

Despite the remaining questions and discussed limitations, I was able to show that first-and-foremost conservative mainstream parties seemingly chase the other "populist zeitgeist" by shifting their policy positions on the GAL-TAN dimension in response to the electoral success of RWPPs. While the question of whether 
mainstream parties can win the electoral race by choosing such a strategy has yet to be answered, bearing current developments in mind, one can conclude that chasing the "populist zeitgeist" might not only lead to losing the race against RWPPs but also induce the risk of losing the marathon, which is the defence of social cohesion and liberal democracy in general.

Funding Open Access funding enabled and organized by Projekt DEAL.

Open Access This article is licensed under a Creative Commons Attribution 4.0 International License, which permits use, sharing, adaptation, distribution and reproduction in any medium or format, as long as you give appropriate credit to the original author(s) and the source, provide a link to the Creative Commons licence, and indicate if changes were made. The images or other third party material in this article are included in the article's Creative Commons licence, unless indicated otherwise in a credit line to the material. If material is not included in the article's Creative Commons licence and your intended use is not permitted by statutory regulation or exceeds the permitted use, you will need to obtain permission directly from the copyright holder. To view a copy of this licence, visit http://creativecommons.org/licenses/by/4. $0 \%$

\section{References}

Abou-Chadi, Tarik. 2016. Niche party success and mainstream party policy shifts—how green and radical right parties differ in their impact. British Journal of Political Science 46(2):417-436.

Abou-Chadi, Tarik, and Werner Krause. 2020. The causal effect of radical right success on mainstream parties' policy positions: a regression discontinuity approach. British Journal of Political Science 50(3):829-847

Adams, James. 2001. Party competition and responsible party government: a theory of spatial competition based upon Insights from behavioral voting research. Ann Arbor: University of Michigan Press.

Adams, James, and Zeynep Somer-Topcu. 2009. Do parties adjust their policies in response to rival parties' policy shifts? Spatial theory and the dynamics of party competition in twenty-five democracies. British Journal of Political Science 39(4):825-846.

Ademmer, Esther, Anna Leupold, and Tobias Stöhr. 2018. Much Ado about nothing? The (non-) politicisation of the European Union in social media debates on migration. European Union Politics 20(2):305-327.

Armingeon, Klaus, Kai Guthmann, and David Weisstanner. 2015. Wie der Euro Europa spaltet. Die Krise der gemeinsamen Währung und die Entfremdung von der Demokratie in der Europäischen Union. Politische Vierteljahresschrift 56(3):506-531.

Arzheimer, Kai, and Carl C. Berning. 2019. How the Alternative for Germany (AfD) and their voters veered to the radical right, 2013-2017. Electoral Studies 60:1-10.

Bakker, Ryan, Liesbet Hooghe, Seth Jolly, Gary Marks, Jonathan Polk, Jan Rovny, Marco Steenbergen, and Milada Anna Vachudova. 2020. 2019 chapel hill expert survey. Version 2019.1. Chapel Hill: University of North Carolina.

Bakker, Ryan, Catherine de Vries, Erica Edwards, Liesbet Hooghe, Seth Jolly, Gary Marks, Jonathan Polk, Jan Rovny, Marco Steenbergen, and Milada Anna Vachudova. 2015. Measuring party positions in Europe: the Chapel Hill expert survey trend file, 1999-2010. Party Politics 21(1):143-152.

Braun, Daniela, and Hermann Schmitt. 2020. Different emphases, same positions? The election manifestos of political parties in the EU multilevel electoral system compared. Party Politics 26(5):640-650.

Budge, Ian. 1994. A new spatial theory of party competition: uncertainty, ideology and policy equilibria viewed comparatively and temporally. British Journal of Political Science 24(4):443-467.

Döring, Holger and Philip Manow. 2019. Parliaments and governments database (ParlGov): Information on parties, elections and cabinets in modern democracies. Development version.

Downes, James F., and Matthew Loveless. 2018. Centre right and radical right party competition in Europe: strategic emphasis on immigration, anti-incumbency, and economic crisis. Electoral Studies 54:148-158.

Downs, Anthony. 1957. An economic theory of political action in a democracy. Journal of Political Economy 65(2):135-150. 
van der Eijk, Cees, and Mark N. Franklin. 2004. Potential for contestation on European matters at national elections in Europe. In European integration and political conflict, ed. Gary Marks, Marco R. Steenbergen, 32-50. Cambridge: Cambridge University Press.

European Social Survey (ESS) Round 1 Data. 2002. Data file edition 6.6. NSD - Norwegian Centre for Research Data, Norway - Data Archive and distributor of ESS data for ESS ERIC. https://doi.org/10. 21338/NSD-ESS1-2002.

European Social Survey (ESS) Round 3 Data. 2006. Data file edition 3.7. NSD - Norwegian Centre for Research Data, Norway - Data Archive and distributor of ESS data for ESS ERIC. https://doi.org/10. 21338/NSD-ESS3-2006.

European Social Survey (ESS) Round 5 Data. 2010. Data file edition 3.4. NSD - Norwegian Centre for Research Data, Norway - Data Archive and distributor of ESS data for ESS ERIC. https://doi.org/10. 21338/NSD-ESS5-2010.

European Social Survey (ESS) Round 7 Data. 2014. Data file edition 2.2. NSD - Norwegian Centre for Research Data, Norway - Data Archive and distributor of ESS data for ESS ERIC. https://doi.org/10. 21338/NSD-ESS7-2014.

European Social Survey (ESS) Round 9 Data. 2018. Data file edition 3.0. NSD - Norwegian Centre for Research Data, Norway - Data Archive and distributor of ESS data for ESS ERIC. https://doi.org/10. 21338/NSD-ESS9-2018.

Guiso, Luigu, Helios Herrera, Massimo Morelli, and Tommaso Sonno. 2017. Demand and supply of populism. CEPR WP No. 610., 1-65.

Han, Kyung Joon. 2015. The impact of radical right-wing parties on the positions of mainstream parties regarding multiculturalism. West European Politics 38(3):557-576.

Harmel, Robert, and Kenneth Janda. 1994. An integrated theory of party goals and party change. Journal of Theoretical Politics 6(3):259-287.

Hawkins, Kirk A. 2009. Is Chávez populist? Measuring populist discourse in comparative perspective. Comparative Political Studies 42(8):1040-1067.

Heinisch, Reinhard, Steven Saxonberg, Annika Werner, and Fabian Habersack. 2021. The effect of radical right fringe parties on main parties in Central and Eastern Europe: Empirical evidence from manifesto data. Party Politics 27(1):9-21.

Hobolt, Sara B. 2016. The Brexit vote: a divided nation, a divided continent. Journal of European Public Policy 23(9):1259-1277.

Hobolt, Sara B., Jae-Jae Spoon, and James Tilley. 2009. A vote against Europe? Explaining defection at the 1999 and 2004 European parliament elections. British Journal of Political Science 39(1):93-115.

Hooghe, Liesbet, and Gary Marks. 2018. Cleavage Theory meets Europe's crises: Lipset, Rokkan, and the transnational cleavage. Journal of European Public Policy 25(1):109-135.

Hooghe, Liesbet, Gary Marks, and Carole J. Wilson. 2002. Does left/right structure party positions on European integration? Comparative Political Studies 35(8):965-989.

Inglehart, Ronald F., and Pippa Norris. 2016. Trump, Brexit, and the rise of populism: economic have-nots and cultural backlash. Faculty Research WP Series Havard Kennedy School RWP16-026., 1-52.

König, Thomas, Moritz Marbach, and Moritz Osnabrügge. 2017. Left/right or U? Estimating the dimensionality of national party competition in Europe. The Journal of Politics 79(3):1101-1105.

Krause, Werner, and Heiko Giebler. 2020. Shifting welfare policy positions: the impact of radical right populist party success beyond migration politics. Representation 56(3):293-306.

Kriesi, Hanspeter. 2010. Restructuration of partisan politics and the emergence of a new cleavage based on values. West European Politics 33(3):673-685.

Kriesi, Hanspeter, and Sven Hutter. 2017. The politicization of European integration and its location in the national political space. presented at Robert Schumann Centre, Florence, 18-19 May 2017., 2-44.

Kriesi, Hanspeter, Edgar Grande, Romain Lachat, Martin Dolezal, Simon Bornschier, and Timotheos Frey. 2006. Globalization and the transformation of the national political space: six European countries compared. European Journal of Political Research 45(6):921-956.

Lipset, Seymour M., and Stein Rokkan. 1967. Party systems and voter alignments: cross-national perspectives, Vol. 7. New York: Free Press.

Lockwood, Matthew. 2018. Right-wing populism and the climate change agenda: exploring the linkages. Environmental Politics 27(4):712-732.

Mair, Peter. 2007. Political opposition and the European Union. Government and Opposition 42(1):1-17.

Marks, Gary, and Carole J. Wilson. 2000. The past in the present: a cleavage theory of party response to European integration. British Journal of Political Science 30(3):433-459.

Mattila, Mikko, and Tapio Raunio. 2006. Cautious voters-supportive parties: Opinion congruence between voters and parties on the EU dimension. European Union Politics 7(4):427-449. 
Mattila, Mikko, and Tapio Raunio. 2012. Drifting further apart: national parties and their electorates on the EU dimension. West European Politics 35:589-606.

Meguid, Bonnie M. 2005. Competition between unequal's: the role of mainstream party strategy in niche party success. American Political Science Review 99(3):347-359.

Meijers, Maurits J. 2017. Contagious Euroscepticism: the impact of Eurosceptic support on mainstream party positions on European integration. Party Politics 23(4):413-423.

Meijers, Maurits J., and Christopher J. Williams. 2020. When shifting backfires: the electoral consequences of responding to niche party EU positions. Journal of European Public Policy 27(10):1506-1525.

Mudde, Cas. 2004. The populist zeitgeist. Government and Opposition 39(4):541-563.

Mudde, Cas. 2007. Populist Radical Right Parties in Europe. Cambridge: Cambridge University Press.

Mudde, Cas. 2013. The 2012 Stein Rokkan lecture: three decades of populist radical right parties in Western Europe: so what? European Journal of Political Research 52(1):1-19.

Mudde, Cas, and Cristobal R. Kaltwasser. 2013. Exclusionary vs. inclusionary populism: comparing contemporary Europe and Latin America. Government and Opposition 48(2):147-174.

Pappas, Christine, Jeanette Mendez, and Rebekah Herrick. 2009. The negative effects of populism on gay and lesbian rights. Social Science Quarterly 90(1):150-163.

Pardos-Prado, Sergi. 2015. How Can mainstream parties prevent niche party success? Centre-right parties and the immigration issue. Journal of Politics 77(2):352-367.

Pelinka, Anton. 2013. Right-wing populism: concept and typology. In Right-wing populism in Europe-politics and discourse, ed. Ruth Wodak, Majid KhosraviNik Majid, and Brigitte Mral, 3-22. London: Bloomsbury.

Polk, Jonathan, Jan Rovny, Ryan Bakker, Erica Edwards, Liesbet Hooghe, Seth Jolly, Jelle Koedam, Filip Kostelka, Gary Marks, Gijs Schumacher, Marco Steenbergen, Milada Anna Vachudova, and Marko Zilovic. 2017. Explaining the salience of anti-elitism and reducing political corruption for political parties in Europe with the 2014 Chapel Hill Expert Survey Data. Research \& Politics. https://doi.org/ $10.1177 / 2053168016686915$.

Prais, Sigbert J., and Christopher B. Winsten. 1954. Trend estimators and serial correlation. Cowles Commission discussion paper Stat No. 383, Chicago.

Rodrik, Dani. 2018. Populism and the economics of globalization. Journal of International Business Policy 1:12-33.

Rooduijn, Matthijs. 2019. State of the field: how to study populism and adjacent topics? A plea for both more and less focus. European Journal of Political Research 58(1):362-372.

Rooduijn, Matthijs, Sarah L. de Lange, and Wouter van der Brug. 2014. A populist zeitgeist? Programmatic contagion by populist parties in Western Europe. Party Politics 20(4):563-575.

Rooduijn, Matthijs M., Stijn van Kessel, Caterina Froio, Andrea Pirro, Sarah de Lange, Daphne Halikiopoulou, Paul Lewis, Cas Mudde, and Paul Taggart. 2019. The PopuList: an overview of populist, far right, far left and Eurosceptic parties in Europe. www.popu-list.org. Accessed 23 Dec 2020.

Rydgren, Jens. 2005. Is extreme right-wing populism contagious? European Journal of Political Research 44:413-437.

Schumacher, Gijs, and Kees van Kersbergen. 2016. Do mainstream parties adapt to the welfare chauvinism of populist parties? Party Politics 22(3):300-312.

Somer-Topcu, Zeynep. 2009. Timely decisions: the effects of past national elections on party policy change. The Journal of Politics 71:238-248.

van Spanje, Joost. 2010. Contagious parties: Anti-immigration parties and their impact on other parties' immigration stances in contemporary Western Europe. Party Politics 16(5):563-586.

van Spanje, Joost, and Wouter van der Brug. 2009. Being intolerant of the intolerant. The exclusion of Western European anti-immigration parties and its consequences for party choice. Acta Politica 44(4):353-384.

van Spanje, Joost, and Nan D. de Graaf. 2018. How established parties reduce other parties' electoral support: the strategy of parroting the pariah. West European Politics 41(1):1-27.

Taggart, Paul. 2000. Populism. Buckingham: Open University Press.

Volkens, Andrea, Tobias Burst, Werner Krause, Pola Lehmann, Theres Matthieß, Nicolas Merz, Sven Regel, Bernhard Weßels, and Lisa Zehnter. 2020. The Manifesto Data Collection. Manifesto Project (MRG/CMP/MARPOR). Berlin: Wissenschaftszentrum Berlin für Sozialforschung (WZB).

de Vries, Catherine E. 2013. Ambivalent Europeans? Public support for European integration in East and West. Government and Opposition 48(3):434-461.

de Vries, Catherine E. 2018. The cosmopolitan-parochial divide: changing patterns of party and electoral competition in the Netherlands and beyond. Journal of European Public Policy 25(11):1541-1565. 
Wagner, Markus, and Thomas M. Meyer. 2017. The radical right as niche parties? The ideological landscape of party systems in Western Europe, 1980-2014. Political Studies 65(1):84-107.

White, Halbert. 1980. A heteroskedasticity-consistent covariance matrix estimator and a direct test for heteroskedasticity. Econometrica: Journal of the Econometric Society 48(4):817-838.

Williams, Laron, and Guy Whitten. 2015. Don't stand so close to me: spatial contagion effects and party competition. American Journal of Political Science 59(2):309-325.

Zaslove, Andrej. 2008. Here to stay? Populism as a new party type. European Review 16(3):319-336. 